\title{
Optimal allocation backs Droop's cell-quota model
}

\author{
Markus Pahlow*, Andreas Oschlies \\ GEOMAR Helmholtz Centre for Ocean Research Kiel, Düsternbrooker Weg 20, 24105 Kiel, Germany
}

ABSTRACT: Droop's cell-quota model is the most successful description of phytoplankton growth in laboratory cultures and is increasingly being introduced into the ecosystem components of biogeochemical models. Although the Droop model's parameters can be easily interpreted in biological terms, it was nevertheless derived empirically and lacks a sound mechanistic foundation. Here we derive Droop's model from a simple optimality condition which maximises net growth rate. Our approach links the maximum cell quota to the cost of nutrient acquisition and suggests that respiration is influenced more strongly by $\mathrm{C}$ fixation than by $\mathrm{N}$ assimilation.

KEY WORDS: Optimality-based model - Cell quota . Droop model

Resale or republication not permitted without written consent of the publisher

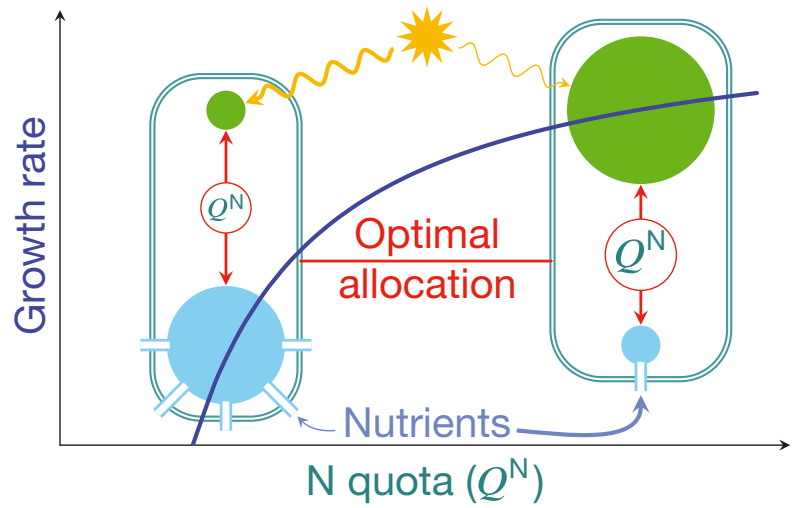

Droop's cell-quota model of growth rate as a function of cell quota (dark blue curve) represents optimal allocation of phytoplankton cellular $\mathrm{N}\left(Q^{\mathrm{N}}\right)$ between light harvesting (green disks) and nutrient acquisition (blue discs with pipes). The optimal allocation responds to the availability (width of light blue and yellow arrows) of both nutrients and light.

Diagram: M. Pahlow

biochemical composition (Flynn 2008), and has been widely used in different variants in $0-, 1$ - and even 2-dimensional global biogeochemical models (e.g. Moore et al. 2002, Mongin et al. 2003, Wirtz \& Pahlow 2010). Similarities to Droop's cell-quota model have even been used to lend support to other modelling approaches. For example, Kooijman (2001) reported that the cell-quota model could, under certain assumptions, be linked to the DEB (dynamic energy budget) theory, and Wirtz \& Pahlow (2010) found that their optimalitybased adaptive dynamics behaved very similarly to Eq. (1). However, the cell-quota model lacks a sound mechanistic underpinning and fails, e.g., to predict a maximum quota (Flynn 2008). In the following, we present an analytical derivation of Droop's cell-quota 
Table 1. Symbol definitions and units. $\hat{\mu}_{\mathrm{g},}^{\mathrm{I}} Q_{\mathrm{s}}^{\mathrm{N}} \hat{V}^{\mathrm{N}}$ (or $\hat{V}_{\mathrm{max}}^{\mathrm{N}}$ ), $\zeta^{\mathrm{C}}$ and $\zeta^{\mathrm{N}}$ are parameters, all others are derived quantities

\begin{tabular}{|c|c|c|}
\hline Symbol & Unit & Definition \\
\hline $\mathrm{C}_{\mathrm{c}}$ & mol cell ${ }^{-1}$ & Chloroplast C \\
\hline $\mathrm{C}_{\mathrm{t}}$ & $\mathrm{mol} \mathrm{cell}^{-1}$ & Total cellular $\mathrm{C}$ \\
\hline$f_{\mathrm{V}}$ & - & $\mathrm{N}$ fraction devoted to $\mathrm{N}$ acquisition \\
\hline$f_{\mathrm{V}}^{\mathrm{o}}$ & - & Optimal $f_{\mathrm{V}}$ \\
\hline$\mu$ & $\mathrm{d}^{-1}$ & Relative growth rate \\
\hline$\hat{\mu}$ & $\mathrm{d}^{-1}$ & Potential relative growth rate \\
\hline$\hat{\mu}^{I}$ & $\mathrm{~d}^{-1}$ & $\begin{array}{l}\text { Potential biomass (C)-normalised } \\
\text { C fixation }\end{array}$ \\
\hline$\hat{\mu}_{g}^{I}$ & $\mathrm{~d}^{-1}$ & $\begin{array}{l}\text { Potential biomass-normalised } \\
\text { gross C fixation }\end{array}$ \\
\hline $\mathrm{N}_{\mathrm{c}}$ & mol cell ${ }^{-1}$ & Chloroplast $\mathrm{N}$ \\
\hline $\mathrm{N}_{\mathrm{s}}$ & mol cell ${ }^{-1}$ & Cellular $\mathrm{N}$ in structural material \\
\hline $\mathrm{N}_{\mathrm{t}}$ & mol cell ${ }^{-1}$ & Total cellular $\mathrm{N}$ \\
\hline$Q$ & $\mathrm{~mol} \mathrm{~mol}^{-1}$ & Cell quota (constituent: $\mathrm{C}_{\mathrm{t}}$ ratio) \\
\hline$Q_{0}$ & $\mathrm{~mol} \mathrm{~mol}^{-1}$ & Minimum (subsistence) cell quota \\
\hline$Q^{\mathrm{N}}$ & $\mathrm{mol} \mathrm{mol}^{-1}$ & Cellular N:C ratio ( $\mathrm{N}$ quota) \\
\hline$Q_{\mathrm{s}}^{\mathrm{N}}$ & $\mathrm{mol} \mathrm{mol}^{-1}$ & Cellular $\mathrm{N}_{\mathrm{s}}: \mathrm{C}_{\mathrm{t}}$ ratio \\
\hline$R$ & $\mathrm{~d}^{-1}$ & Relative respiration rate \\
\hline$V^{\mathrm{N}}$ & $\mathrm{mol} \mathrm{mol}{ }^{-1} \mathrm{~d}^{-1}$ & $\begin{array}{l}\text { Biomass (C)-normalised } \mathrm{N} \\
\text { acquisition }\end{array}$ \\
\hline$V_{\max }^{\mathrm{N}}$ & $\mathrm{mol} \mathrm{mol}^{-1} \mathrm{~d}^{-1}$ & $\begin{array}{l}\text { Maximum biomass-normalised } \mathrm{N} \\
\text { acquisition }\end{array}$ \\
\hline$\hat{V}^{\mathrm{N}}$ & $\mathrm{mol} \mathrm{mol}{ }^{-1} \mathrm{~d}^{-1}$ & $\begin{array}{l}\text { Potential biomass-normalised N } \\
\text { acquisition }\end{array}$ \\
\hline$\hat{V}_{\max }^{\mathrm{N}}$ & $\mathrm{mol} \mathrm{mol}^{-1} \mathrm{~d}^{-1}$ & $\begin{array}{l}\text { Max. potential biomass- } \\
\text { normalised N acquisition }\end{array}$ \\
\hline$\zeta^{\mathrm{C}}$ & - & Respiration cost of $\mathrm{C}$ fixation \\
\hline$\zeta^{\mathrm{N}}$ & $\mathrm{mol} \mathrm{mol}^{-1}$ & $\begin{array}{l}\text { Respiration cost of } \mathrm{N} \text { uptake and } \\
\text { assimilation }\end{array}$ \\
\hline
\end{tabular}

model (Eq. 1) from a simple optimality condition, which maximises balanced, nitrogen-limited growth and also yields predictions about respiration and the maximum cell quota. Symbol definitions and units are given in Table 1.

\section{OPTIMALITY-BASED DERIVATION OF DROOP'S CELL-QUOTA MODEL}

Optimality provides a powerful conceptual basis for the formulation of phytoplankton growth models (Shuter 1979, Smith et al. 2011). Here we derive an optimality condition by balancing respiration and allocation costs against benefits of nutrient acquisition. Respiration (energy) costs of nutrient acquisition are assumed proportional to nutrient acquisition. Allocation costs are formulated as an assumption that a fixed amount of cellular nitrogen $(\mathrm{N})$, represented by the biomass-normalised $\mathrm{N}$ cell quota ( $\mathrm{N}$ : $\mathrm{C}$ ratio, $Q^{\mathrm{N}}$ ), is bound in structural material and the remainder is allocated between requirements for $\mathrm{C}$ and $\mathrm{N}$ acquisition (Fig. 1A). Potential $\mathrm{C}$ and $\mathrm{N}$ acquisition are assumed proportional to the respective relative sizes of the chloroplast ( $\mathrm{C}$ fixation) and the $\mathrm{N}$ acquisition machinery. We define the allocation factor $f_{\mathrm{V}}$ as the fraction of cellular $\mathrm{N}$ invested in the $\mathrm{N}$-acquisition machinery (Wirtz \& Pahlow 2010). For conceptual simplicity, it is assumed here that $\mathrm{N}$ and $\mathrm{C}$ are allocated in parallel, implying the same $\mathrm{N}$ : C ratio in the

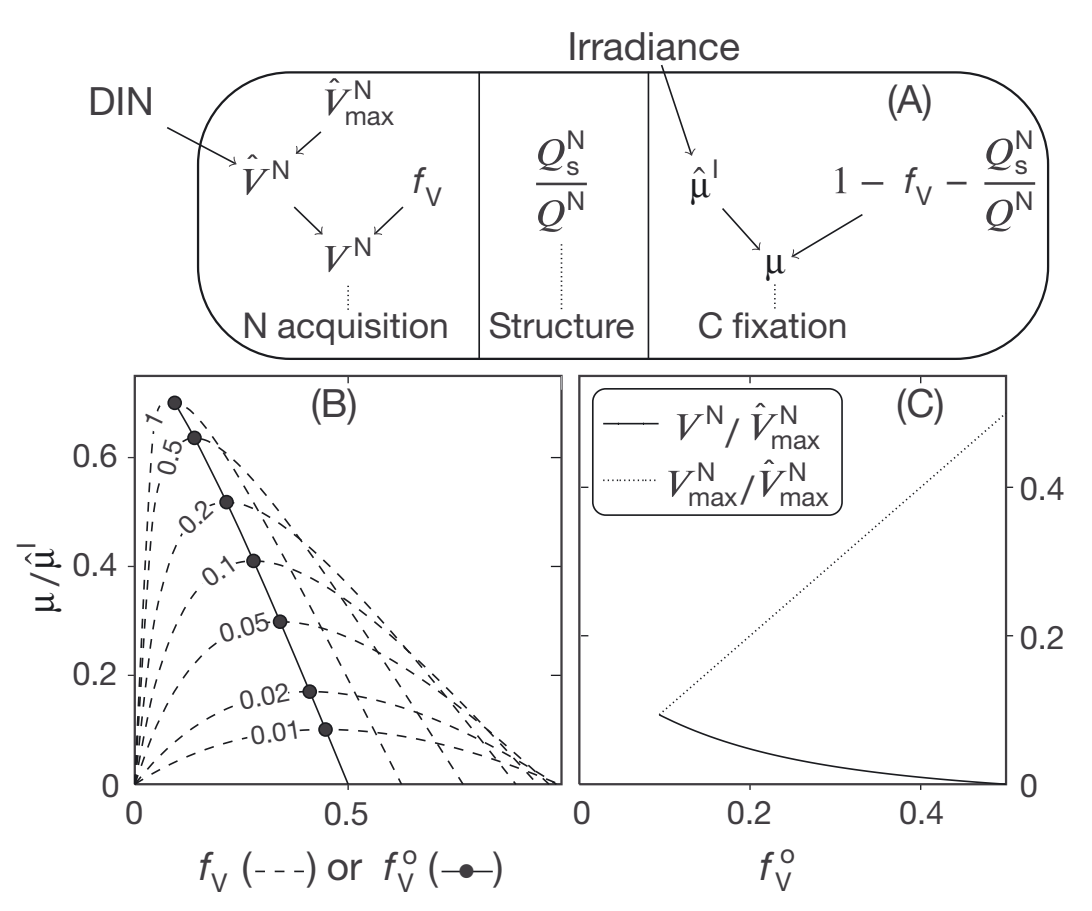

Fig. 1. (A) Schematic diagram of $\mathrm{N}$ allocation via the allocation factor $f_{\mathrm{V}}$ among $\mathrm{N}$ acquisition (protoplast), structure and $\mathrm{C}$ fixation (chloroplast). Dissolved inorganic nitrogen (DIN) concentration and maximum potential $\mathrm{N}$ uptake $\left(\hat{V}_{\max }^{\mathrm{N}}\right)$ determine potential $\mathrm{N}$ uptake $\left(\hat{V}^{\mathrm{N}}\right)$. $\mathrm{N}$ allocation to $\mathrm{N}$ acquisition $\left(f_{\mathrm{V}}\right)$ then controls actual $\mathrm{N}$ uptake $\left(V^{\mathrm{N}}\right)$. The fraction of cellular $\mathrm{N}$ not allocated to $\mathrm{N}$ acquisition and structural material $\left(1-f_{\mathrm{V}}-Q_{\mathrm{s}}^{\mathrm{N}} / Q^{\mathrm{N}}\right)$ and the light-dependent potential maximum relative growth rate $\left(\hat{\mu}^{\mathrm{I}}\right)$ control $\mathrm{C}$ fixation, together with the cost of $\mathrm{N}$ assimilation ( $\zeta^{\mathrm{N}}$, not shown). (B) Relation between relative growth rate $(\mu$, normalised to $\hat{\mu}^{\mathrm{I}}$ ) and $f_{\mathrm{V}}$ (dashed lines; line labels indicate the saturation of the $\mathrm{N}$ uptake apparatus $\left.\left[\hat{V}^{\mathrm{N}} / \hat{V}_{\max }^{\mathrm{N}}\right]\right)$. Filled circles indicate the maximum of each curve, corresponding to $f_{\mathrm{V}}^{\mathrm{o}}$ i the solid line describes the optimally acclimated behaviour. (C) Relation between $f_{\mathrm{V}}^{\mathrm{o}}$ and actual $\left(V^{\mathrm{N}}\right)$ and maximum $\mathrm{N}$ uptake $\left(V_{\max }^{\mathrm{N}}\right)$, both normalised to maximum potential $\mathrm{N}$ uptake $\left(\hat{V}_{\max }^{\mathrm{N}}\right) . V_{\max }^{\mathrm{N}}$ is highest in nutrient-starved cells (high $f_{\mathrm{V}}^{\mathrm{O}}$ ), allowing for quick uptake once nutrients become available. Panels $\mathrm{B}$ and $\mathrm{C}$ are for $\hat{\mu}^{\mathrm{I}}=1 \mathrm{~d}^{-1}, \hat{V}_{\max }^{\mathrm{N}}=1 \mathrm{~mol} \mathrm{~mol}^{-1} \mathrm{~d}^{-1}$, $Q_{\mathrm{s}}^{\mathrm{N}}=0.02 \mathrm{~mol} \mathrm{~mol}^{-1}$ and $\zeta^{\mathrm{N}}=0.6 \mathrm{~mol} \mathrm{~mol}^{-1}$. See Table 1 for full symbol definitions 
chloroplast as in the whole cell (Pahlow \& Oschlies 2009). The relative size (in terms of biomass) of the chloroplast is then:

$\frac{N_{\mathrm{c}}}{\mathrm{C}_{\mathrm{c}}}=\frac{N_{\mathrm{t}}}{\mathrm{C}_{\mathrm{t}}} \Leftrightarrow \frac{C_{\mathrm{c}}}{\mathrm{C}_{\mathrm{t}}}=\frac{N_{\mathrm{c}}}{\mathrm{N}_{\mathrm{t}}}=\frac{N_{\mathrm{t}}-N_{\mathrm{s}}-f_{\mathrm{v}} N_{\mathrm{t}}}{N_{\mathrm{t}}}=1-\frac{Q_{\mathrm{s}}^{\mathrm{N}}}{Q^{\mathrm{N}}}-f_{\mathrm{v}}$

where the subscripts $\mathrm{C}$, $\mathrm{s}$ and $\mathrm{t}$ indicate the chloroplast, structural material and whole cell, respectively. Now we define the local, i.e. compartment-specific, biomassnormalised rates of net $\mathrm{C}$ and $\mathrm{N}$ acquisition as $\hat{\mu}^{\mathrm{I}}$ and $\hat{V}^{\mathrm{N}}$, respectively, where the superscripts refer to external dependencies: $\hat{\mu}^{\mathrm{I}}$ is a function of irradiance and $\hat{V}^{\mathrm{N}}$ is a saturating function of ambient dissolved inorganic nitrogen (DIN) with an inherent maximum, $\hat{V}_{\max }^{\mathrm{N}}$ (Fig. 1A). Thus, light dependency is associated with the chloroplast and DIN dependency is associated with the nutrient-acquisition compartment. Then the actual rates of net $\mathrm{C}$ and $\mathrm{N}$ acquisition, $\mu^{\mathrm{I}}$ and $V^{\mathrm{N}}$, respectively, can be calculated as the products of the local rates and relative sizes of the corresponding compartments:

$$
\begin{gathered}
\mu^{\mathrm{I}}=\hat{\mu}^{\mathrm{I}}\left(1-\frac{Q_{\mathrm{s}}^{\mathrm{N}}}{Q^{\mathrm{N}}}-f_{\mathrm{V}}\right) \\
V^{\mathrm{N}}=f_{\mathrm{V}} \hat{V}^{\mathrm{N}}
\end{gathered}
$$

Net relative growth rate $(\mu)$ can be defined as the balance of net $\mathrm{C}$ fixation by the chloroplast and respiration costs of $\mathrm{N}$ acquisition, such that,

$$
\mu=\mu^{\mathrm{I}}-\zeta^{\mathrm{N}} V^{\mathrm{N}}=\hat{\mu}^{\mathrm{I}}\left(1-\frac{Q_{\mathrm{s}}^{\mathrm{N}}}{Q^{\mathrm{N}}}-f_{\mathrm{v}}\right)-\zeta^{\mathrm{N}} f_{\mathrm{v}} \hat{V}^{\mathrm{N}}
$$

where $\zeta^{\mathrm{N}}$ is the cost of $\mathrm{N}$ uptake and assimilation. Note that both local rates may comprise both gain and loss terms, e.g., $\hat{\mu}^{\mathrm{I}}$ represents the balance between gross $\mathrm{C}$ fixation and the associated respiration costs within the chloroplast. While the precise forms of the light and DIN functions $\hat{\mu}^{\mathrm{I}}$ and $\hat{V}^{\mathrm{N}}$ do not matter for the present analysis, they must not depend on $Q^{\mathrm{N}}$ or $f_{\mathrm{V}}$, as we require that Eq. (5) is explicit in these 2 quantities.

In order to find the optimal allocation $\left(f_{\mathrm{V}}^{\circ}\right)$ between nutrient acquisition and light harvesting, $Q^{\mathrm{N}}$ is eliminated from Eq. (5) with the help of the balancedgrowth approximation:

$\mu Q^{\mathrm{N}}=V^{\mathrm{N}}=f_{\mathrm{V}} \hat{V}^{\mathrm{N}} \Leftrightarrow Q_{\mathrm{s}}^{\mathrm{N}} \frac{\hat{\mu}^{\mathrm{I}}}{\hat{V}^{\mathrm{N}}}+f_{\mathrm{V}}=Q^{\mathrm{N}}\left[\frac{\hat{\mu}^{\mathrm{I}}}{\hat{V}^{\mathrm{N}}}\left(1-f_{\mathrm{V}}\right)-\zeta^{\mathrm{N}} f_{\mathrm{V}}\right](6)$

whence the optimality condition for the optimal allocation factor ( $f_{\mathrm{V} i}^{\mathrm{o}}$ Fig. 1B) can be defined for balanced growth as:

$\frac{\mathrm{d} \mu}{\mathrm{d} f_{\mathrm{V}}} \stackrel{!}{=} 0 \Leftrightarrow f_{\mathrm{V}}^{\circ 2}+2 f_{\mathrm{v}}^{\circ} Q_{\mathrm{s}}^{\mathrm{N}} \frac{\hat{\mu}^{\mathrm{I}}}{\hat{V}^{\mathrm{N}}}-\frac{Q_{\mathrm{s}}^{\mathrm{N}}}{\frac{\hat{V}^{\mathrm{N}}}{\hat{\mu}^{\mathrm{I}}}\left(1+\zeta^{\mathrm{N}} \frac{\hat{V}^{\mathrm{N}}}{\hat{\mu}^{\mathrm{I}}}\right)}=0$
The above quadratic equation is readily solved for the optimal allocation factor $f_{\mathrm{V}}^{\circ}$ as a function of prescribed model parameters $\left(\zeta^{\mathrm{N}}\right.$ and $\left.Q_{\mathrm{s}}^{\mathrm{N}}\right)$ and external conditions entering the $\mathrm{C}$ and $\mathrm{N}$ acquisition terms $\left(\hat{\mu}^{\mathrm{I}}\right.$ and $\left.\hat{V}^{\mathrm{N}}\right)$. In order to relate our optimality-based concept to Droop's model (Eq. 1), Eq. (6) is rearranged to yield an expression for $\hat{\mu}^{\mathrm{I}} / \hat{V}^{\mathrm{N}}$, which is substituted in Eq. (7) to obtain:

$\left[f_{\mathrm{v}}^{\circ}-\left(1+\zeta^{\mathrm{N}} Q_{\mathrm{s}}^{\mathrm{N}}\right)\right]\left[f_{\mathrm{V}}^{\mathrm{o}}-\frac{Q_{\mathrm{s}}^{\mathrm{N}}}{Q^{\mathrm{N}}}+\zeta^{\mathrm{N}}\left(Q^{\mathrm{N}}-2 Q_{\mathrm{s}}^{\mathrm{N}}\right)\right]=0$

With the obvious condition $0<f_{\mathrm{V}}^{\mathrm{o}}<1$, the second term has to be zero, i.e.

$$
f_{\mathrm{v}}^{\circ}=\frac{Q_{\mathrm{s}}^{\mathrm{N}}}{Q^{\mathrm{N}}}-\zeta^{\mathrm{N}}\left(Q^{\mathrm{N}}-2 Q_{\mathrm{s}}^{\mathrm{N}}\right)
$$

$f_{\mathrm{V}}^{\circ}$ is highest for nutrient-starved cells, i.e. $V_{\max }^{\mathrm{N}}$ approaches its maximum as $V^{\mathrm{N}} \rightarrow 0$ (Fig. 1C), thus providing the means for efficient uptake once nutrient concentrations rise. Substituting Eq. (9) into Eq. (6) yields $Q^{\mathrm{N}}$ as:

$$
Q^{\mathrm{N}}=Q_{\mathrm{s}}^{\mathrm{N}}\left[1+\sqrt{1+\frac{1}{Q_{\mathrm{s}}^{\mathrm{N}}\left(\frac{\hat{\hat{\mu}}^{\mathrm{I}}}{\hat{V}^{\mathrm{N}}}+\zeta^{\mathrm{N}}\right)}}\right]
$$

which allows analysis of the limit behaviour of the optimal allocation model: maximal $Q^{\mathrm{N}}$ occurs under extreme light limitation, i.e. as $\hat{\mu}^{\mathrm{I}} / \hat{V}^{\mathrm{N}} \rightarrow 0$, and $Q^{\mathrm{N}}$ approaches $2 Q_{\mathrm{s}}^{\mathrm{N}}$ as $\hat{V}^{\mathrm{N}} \rightarrow 0$. Substituting $2 Q_{\mathrm{s}}^{\mathrm{N}}$ as the lower limit for $Q^{\mathrm{N}}$ in Eq. (9) yields the upper limit of $f_{\mathrm{V}}^{o}$ as 0.5 (Fig. 1B). Thus, while the respiration cost $\left(\zeta^{N}\right)$ of $\mathrm{N}$ acquisition strongly affects the lower limit of $f_{\mathrm{V}}^{\circ}$, this does not apply to the upper limit because the respiration term $\left(\zeta^{\mathrm{N}} V^{\mathrm{N}}\right)$ in Eq. (5) vanishes as $V^{\mathrm{N}} \rightarrow 0$.

After eliminating $\hat{V}^{\mathrm{N}}$ from Eq. (5) with the help of Eq. (6) and substituting $f_{\mathrm{V}}^{\circ}$ from Eq. (9) for $f_{\mathrm{V}}$, Eq. (5) reduces to Droop's cell-quota model for balanced, $\mathrm{N}$-(co-)limited growth under constant irradiance (for which $\hat{\mu}^{\mathrm{I}}$ is constant):

$$
\mu=\hat{\mu}^{I}\left(1-2 \frac{Q_{\mathrm{s}}^{\mathrm{N}}}{Q^{\mathrm{N}}}\right)
$$

which is of the same form as Eq. (1), with $\hat{\mu} \equiv \hat{\mu}^{\mathrm{I}}, Q \equiv$ $Q^{\mathrm{N}}$ and $Q_{0} \equiv 2 Q_{\mathrm{s}}^{\mathrm{N}}$. This derivation shows that Droop's cell-quota model can be understood as a manifestation of optimal growth.

\section{RESPIRATION}

Furthermore, Eq. (5) explicitly links growth to respiration as a corollary of balancing $\mathrm{C}$ fixation gains against respiratory costs of $\mathrm{N}$ acquisition. The fact 

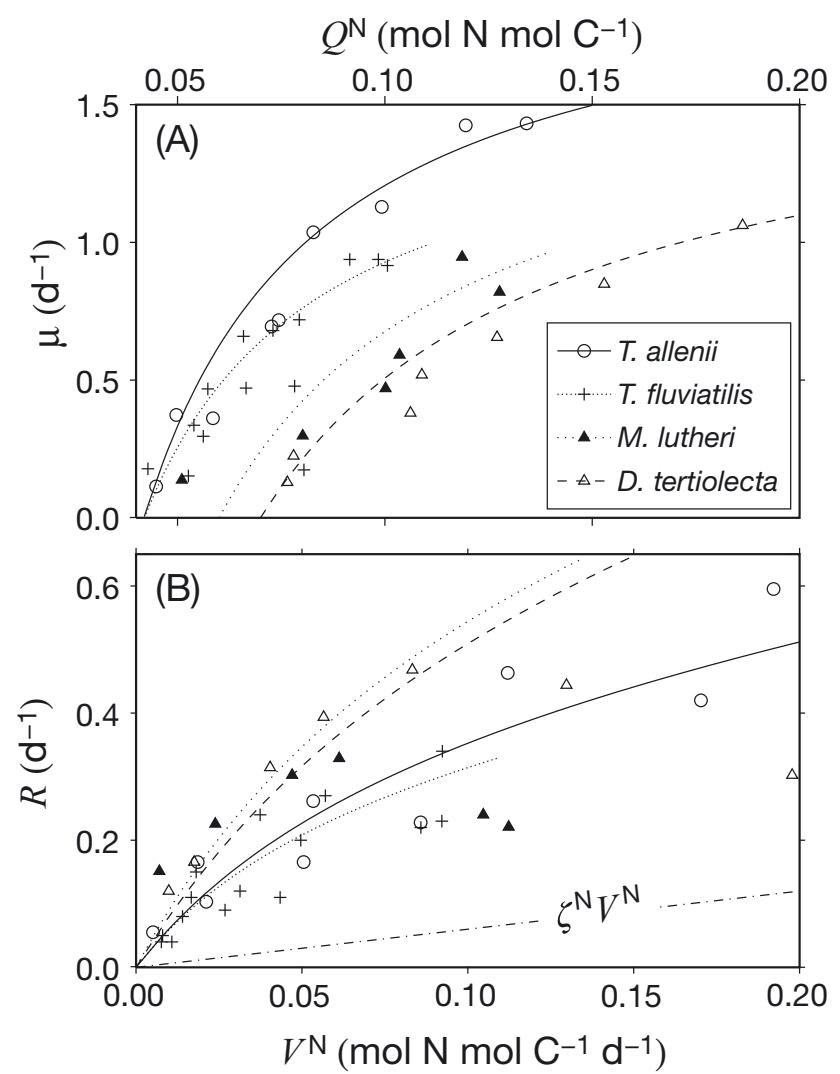

Fig. 2. (A) Growth rate $(\mu)$ as a function of $N$ cell quota (N:C ratio) and (B) respiration $(R)$ as a function of nutrient uptake rate $\left(V^{\mathrm{N}}=\mu Q^{\mathrm{N}}\right)$. Symbols are observations from Laws \& Bannister (1980) for Thalassiosira fluviatilis, and from Laws \& Wong (1978) for Thalassiosira allenii, Monochrysis lutheri and Dunaliella tertiolecta. Lines are model predictions, with $\hat{\mu}_{\mathrm{g}}^{\mathrm{I}}=2.6 \mathrm{~d}^{-1}$ (except $\hat{\mu}_{\mathrm{g}}^{\mathrm{I}}=2 \mathrm{~d}^{-1}$ for T. fluviatilis), $\zeta^{\mathrm{N}}=0.6 \mathrm{~mol} \mathrm{C}$ $\mathrm{mol}^{-1} \mathrm{~N}$ for all 4 species, $Q_{\mathrm{s}}^{\mathrm{N}}=0.021,0.021,0.03$ and 0.035 $\mathrm{mol} \mathrm{N} \mathrm{mol}{ }^{-1} \mathrm{C}$, and $\zeta^{\mathrm{C}}=0.2,0.2,0.35$ and 0.35 , respectively. The dash-dotted line in Panel B indicates the cost of nitrogen acquisition $\left(\zeta^{\mathrm{N}} V^{\mathrm{N}}\right)$

that neither $\hat{V}^{\mathrm{N}}$ nor $\zeta^{\mathrm{N}}$ appear in Eq. (11) might explain the universality of this relation. However, it also means that observations of growth rate as a function of cell quota alone contain no information about the kinetics and associated costs of nutrient acquisition, which must hence be determined by other means. Laws \& Bannister (1980) presented cellquota observations with $Q^{\mathrm{N}}$ varying between 0.04 $\left(\rightarrow Q_{\mathrm{s}}^{\mathrm{N}}=0.02\right)$ and $0.2 \mathrm{~mol} \mathrm{~N} \mathrm{~mol}^{-1} \mathrm{C}$, likely encompassing close to the full range for Thalassiosira fluviatilis, as their cultures comprised both strong nutrient and strong light limitation. We use this range to obtain a rough estimate for $\zeta^{\mathrm{N}}$ from Eq. (10), giving about $0.6 \mathrm{~mol} \mathrm{C} \mathrm{mol}^{-1} \mathrm{~N}$. This is much lower than previous estimates of around $2 \mathrm{~mol} \mathrm{C} \mathrm{mol}^{-1} \mathrm{~N}$, based on some of the data in Fig. 2B (Geider et al. 1998) or theoretical considerations (Pahlow 2005), which implies that a significant fraction of dark respiration cannot be attributed directly to nutrient acquisition. A relatively simple way to reconcile observed respiration rates with our optimal allocation model is to consider the contribution of the cost of photosynthesis, implicitly contained in $\hat{\mu}^{\mathrm{I}}$, to total respiration. The cost of photosynthesis here represents dark-respiration costs related to all metabolic activities, e.g., protein turnover (Quigg \& Beardall 2003), other than nutrient acquisition. We define $\zeta^{\mathrm{C}}$ as the fraction of respiration losses within the chloroplast, $\hat{\mu}^{\mathrm{I}}=\hat{\mu}_{\mathrm{g}}^{\mathrm{I}}(1-$ $\left.\zeta^{\mathrm{C}}\right)$, so that respiration $(R)$ can be written as:

$$
R=\zeta^{\mathrm{C}} \hat{\mu}_{\mathrm{g}}^{\mathrm{I}}\left(1-\frac{Q_{\mathrm{s}}^{\mathrm{N}}}{Q^{\mathrm{N}}}-f_{\mathrm{v}}^{\circ}\right)+\zeta^{\mathrm{N}} V^{\mathrm{N}}
$$

where $\hat{\mu}_{g}^{I}$ is gross C fixation with respect to the chloroplast. Model predictions from Eqs. (11) \& (12) are shown in Fig. 2. The cost of photosynthesis actually dominates $R$, whereas the cost of $\mathrm{N}$ acquisition $\left(\zeta^{\mathrm{N}} V^{\mathrm{N}}\right)$ contributes only roughly 5 to $25 \%$ (dash-dotted line in Fig. 2B). While a linear dependence of $R$ on $V^{\mathrm{N}}$ (e.g. Shuter 1979, Geider et al. 1998) would fit the observations in Fig. 2B similarly well, this would result in an unrealistically high maintenance respiration ( $y$-intercept) of about $0.1 \mathrm{~d}^{-1}$ (not shown). Our optimal allocation model does not suffer from this problem.

Acknowledgements. This work is a contribution of the Sonderforschungsbereich 754 'Climate-Biogeochemistry Interactions in the Tropical Ocean' (www.sfb754.de), which is funded by the German Science Foundation (DFG). This article benefitted from the input of 3 anonymous reviewers.

\section{LITERATURE CITED}

Droop MR (1968) Vitamin B12 and marine ecology. IV. The kinetics of uptake, growth and inhibition in Monochrysis lutheri. J Mar Biol Assoc UK 48:689-733

Droop MR (1973) Some thoughts on nutrient limitation in algae. J Phycol 9:264-272

Droop MR (1983) 25 years of algal growth kinetics. Bot Mar 26:99-112

Flynn KJ (2008) Use, abuse, misconceptions and insights from quota models - the Droop cell quota model 40 years on. Oceanogr Mar Biol Annu Rev 46:1-23

Geider RJ, MacIntyre HL, Kana TM (1998) A dynamic regulatory model of phytoplanktonic acclimation to light, nutrients, and temperature. Limnol Oceanogr 43:679-694

Kooijman SALM (2001) Quantitative aspects of metabolic organization: a discussion of concepts. Philos Trans R Soc Lond B Biol Sci 356:331-349

Laws EA, Bannister TT (1980) Nutrient and light limited growth of Thalassiosira fluviatilis in continuous culture, with implications for phytoplankton growth in the ocean. Limnol Oceanogr 25:457-473

Laws EA, Wong DCL (1978) Studies of carbon and nitrogen 
metabolism by three marine phytoplankton species in nitrate-limited continuous culture. J Phycol 14:406-416

Mongin M, Nelson DM, Pondaven P, Brzezinski MA, Tréguer P (2003) Simulation of upper-ocean biogeochemistry with a flexible-composition phytoplankton model: C, N and Si cycling in the western Sargasso Sea. Deep-Sea Res I 50:1445-1480

Moore JK, Doney SC, Kleypas JA, Glover DM, Fung IY (2002) An intermediate complexity marine ecosystem model for the global domain. Deep-Sea Res II 49:403-462

Pahlow M (2005) Linking chlorophyll-nutrient dynamics to the Redfield N:C ratio with a model of optimal phytoplankton growth. Mar Ecol Prog Ser 287:33-43

Editorial responsibility: Katherine Richardson, Copenhagen, Denmark
Pahlow M, Oschlies A (2009) Chain model of phytoplankton P, N and light colimitation. Mar Ecol Prog Ser 376:69-83

- Quigg A, Beardall J (2003) Protein turnover in relation to maintenance metabolism at low photon flux in two marine microalgae. Plant Cell Environ 26:693-703

Shuter B (1979) A model of physiological adaptation in unicellular algae. J Theor Biol 78:519-552

Smith SL, Pahlow M, Merico A, Wirtz KW (2011) Optimalitybased modeling of planktonic organisms. Limnol Oceanogr 56:2080-2094

Wirtz KW, Pahlow M (2010) Dynamic chlorophyll and nitrogen:carbon regulation in algae optimizes instantaneous growth rate. Mar Ecol Prog Ser 402:81-96

Submitted: June 25, 2012; Accepted: November 14, 2012

Proofs received from author(s): January 4, 2013 